Afr. J. Trad. CAM (2004) 1: 72 - 76

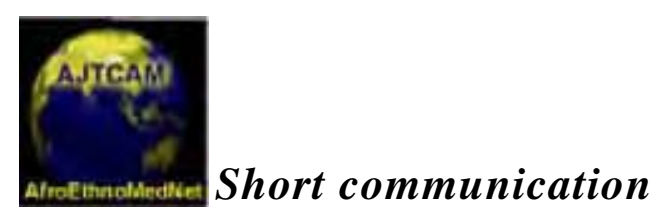

Afr. J. Traditional,

Complementary and Alternative

Medicines

www.africanethnomedicines.net

\title{
SOME MEDICINAL PLANTS USED IN YEMENI HERBAL MEDICINE TO TREAT MALARIA
}

\author{
Awadh A. N. Ali* ${ }^{2,1}$, K. Al-rahwi ${ }^{1}$ and U. Lindequist ${ }^{3}$ \\ Pharmacognosy Department, Faculty of Medicine and Health Sciences, Sana'a \\ University ${ }^{1}$, and Aden University ${ }^{2}$ Yemen, Department of Pharmaceutical Biology, \\ Institute of Pharmacy, Ernst-Moritz-Arndt- University, Germany ${ }^{3}$ \\ * corresponding author: email : biniali@y.net.ye
}

\begin{abstract}
This pilot study examined the extent and the type of medicinal plants used for treating malaria. 492 informants were interviewed in 13 villages located on the coastal plain of four provinces. Nineteen plants belonging to fourteen families were recorded each with local names, methods of preparation and parts used. The antimalarial traditional uses of Dodonaea viscosa, Plantago major, Cissus rotundifolia, Citrullus colocynthis, Anisotes trisulcus, and Tamarindus indica had been reported for the first time.
\end{abstract}

Key words: antimalarial uses; traditional medicine, Yemen

\section{Introduction:}

Malaria is an endemic disease particularly in regions of Africa, Asia and South America, where it is distributed widely. Mainly due to the multidrug resistance developed by Plasmodium falciparum, malaria remains the leading cause of death due to parasitic diseases with approximately 300 million clinical cases annually resulting in an estimated 2.300 .000 deaths, primarily in children.(WHO-report 1996)

This spread of drug-resistance increases the need for new antimalarial drugs with novel mechanisms of pharmacological action. The success of artemisinin, isolated from Artemisia.аnпиа, and its derivatives for the treatment of resistant malaria has focused attention on the plants, as a source of antimalarial drugs (Tan, R., et al 1998). Ethnobotanical information about antimalarial plants, used in traditional herbal medicine, is essential for the further evaluation of the efficacy of plant antimalarial remedies and for isolating and identifying of new antimalarial drugs.

Most of the Yemeni people living in rural areas depends on traditional herbal medicine for 
the treatment of many infectious diseases such as malaria (Ali et al 1999). In this study, we document some ethnomedical information of medicinal plants, used as antimalarial remedies in rural areas in Yemen.

\section{Subjects and methods}

\section{Study area and population.}

The present study is dealing with 13 villages scattered on the coastal plain of four provinces Hudaidah, Taiz, Abyan, and Hadramout, with approx. 11,000 inhabitants, mostly living on agriculture $(55 \%)$ and fishing $(25 \%)$. The surveyed areas lie between $13^{\circ} 8^{\prime}-14^{\circ} 2^{\prime}$ North latitude and $45^{\circ} 22^{\prime}-47^{\circ} 39^{\prime}$ East longitude. About $65 \%$ of the territory is exploited for producing cereals, banana, and papaya. It is almost entirely flat, rising from the sea level to $100-200 \mathrm{~m}$. The weather is uniformely hot and humid, temperature rarely falling below $10^{\circ}$ $\mathrm{C}$ at night and rising to $35^{\circ} \mathrm{C}$ during the day, little variations between summer and winter.

\section{Methodology:}

Field trips (5-8 days each) on the surveyed 13 villages were conducted during Spring in 1998-1999. The ethnobotanical data was collected through interviews held with 492 informants [25 traditional healers, 365 old (male and female) and 49 young farmers, 53 fishermen] and recorded on field note books. Photos and herbarium dried specimens of the used medicinal plants were prepared. All vouchers were taxonomically identified by A. Alkhulidi, Agricultural Research Center in Dhamar, and deposited in the Herbarium of the Pharmacognosy Department, Sana'a University.

\section{Results and Discussions}

Traditional medicine and ethnobotanical information play an important role today as subject for scientific research, particularly when the literature and field work data have been properly evaluated. The result of such assessment can provide a number of plants which can claim priority to be investigated for a selected biological activity or efficacy against a selected disorder or disease. This pilot study includes the traditional uses of 19

plants, collected from four provinces, Hudaidah, Taiz, Abyan, and Hadramout which are used in the Yemeni herbal medicine for treating of malaria (Table 1).

Most of the remedies have been taken orally in form of decoction or infusion and paste.

No reports regarding antimalarial traditional local uses of the reported plants have been found in previous recorded literature (Schoppen A, 1983, Fleurentin, J, 1982, 1983a and 1983b). The antimalarial activity of the diluted latex obtained from $A$. vera and the infusion of the $C$. italica leaves may be explained on the light of the presence of anthraquinones and other quinoid compounds which exert good activity against $P$. falciparum (Sittie A. A. et al 1999). Antimalarial activity of $C$. rotundus was reported (Thebtaranonth, $C$ et al 1995).

The presence of triterpenoids, limonoids, in A. indica may take part in the antimalarial activity of the traditional herbal medicines. It is known that the limonoid gedunin (MacKinnon, S., 1997), isolated from A. indica, exerts antimalarial effect in vitro. The antimalarial uses of Dodonaea viscosa, Ruta chalepensis, Plantago major, Cissus 


\begin{tabular}{|c|c|c|c|c|c|c|c|c|c|c|c|}
\hline$\frac{0}{5} b^{\circ}$ & $\stackrel{\mathscr{m}}{\ddot{g}}$ & & $\overrightarrow{\dot{\rho}}$ & $\vec{\sim}$ & $a$ & $\underline{\underline{b}}$ & $\infty_{\infty}^{\infty}$ & iे & $\frac{n}{m}$ & lin & $\begin{array}{l}\text { ले } \\
\text { mat }\end{array}$ \\
\hline & 16 & $\stackrel{\widetilde{\Omega}}{\mathrm{S}}$ & $\underset{d}{\infty}$ & 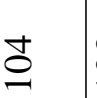 & 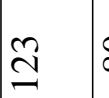 & $\infty$ & $\stackrel{\infty}{\infty}$ & f & $\stackrel{n}{n}$ & $\underline{\Sigma}$ & $\widehat{\underline{\sigma}}$ \\
\hline 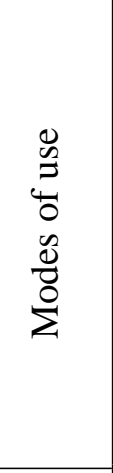 & 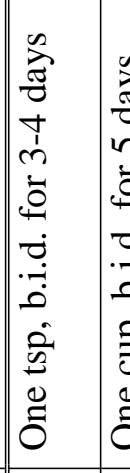 & 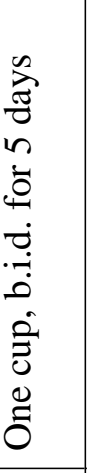 & . & 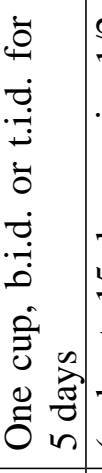 & 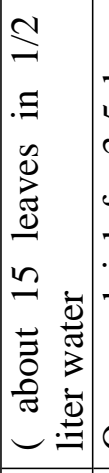 & 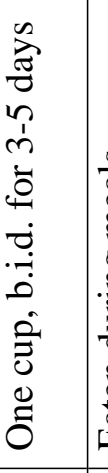 & 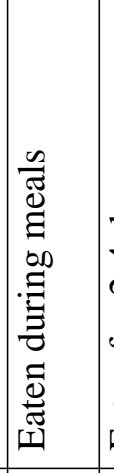 & 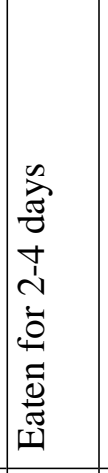 & 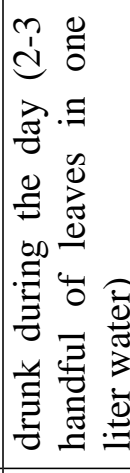 & 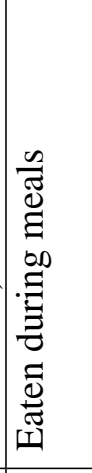 & 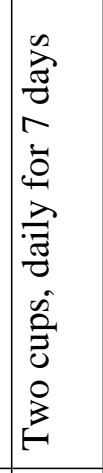 \\
\hline 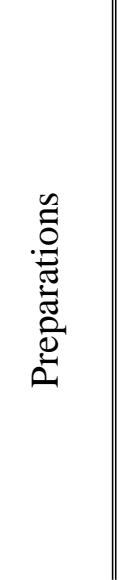 & 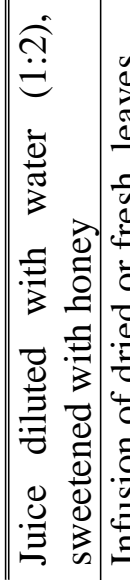 & 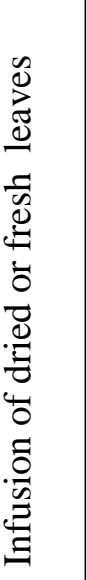 & 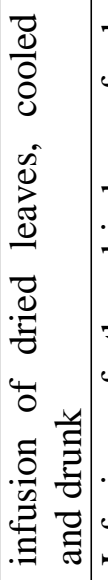 & 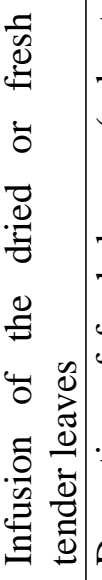 & 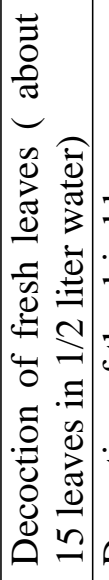 & 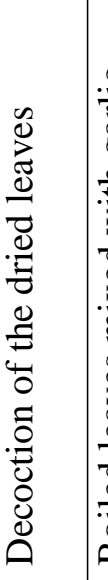 & 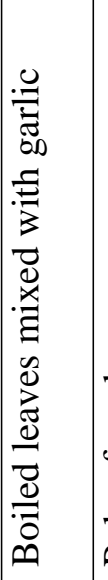 & 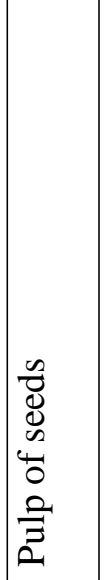 & 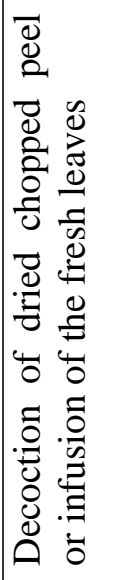 & 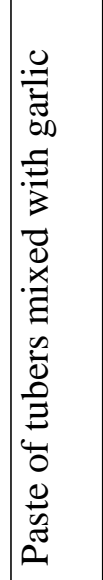 & 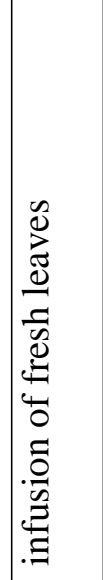 \\
\hline 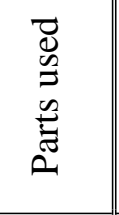 & 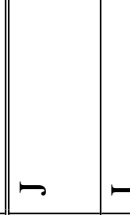 & ــ & - & ـــ & دـ & ــ & ــ & in & $\vec{Q}$ & $H$ & ــ \\
\hline 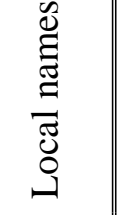 & 童 & 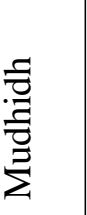 & 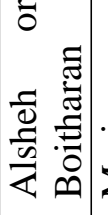 & & 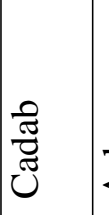 & $\frac{\vec{E}}{\frac{\pi}{x}}$ & , & 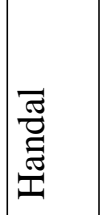 & 吾 & 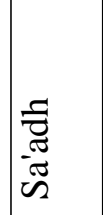 & 㺃 \\
\hline 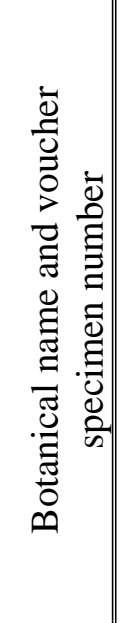 & 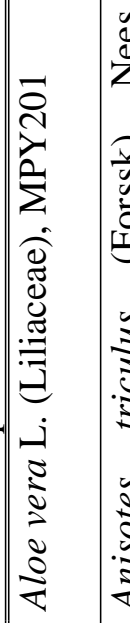 & 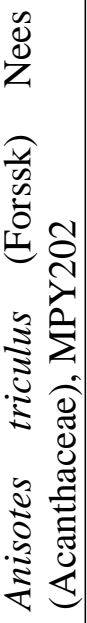 & . & : & 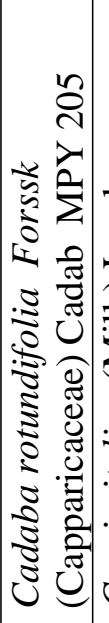 & 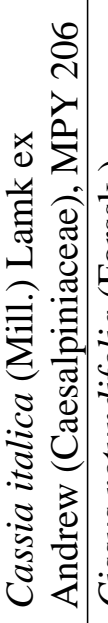 & 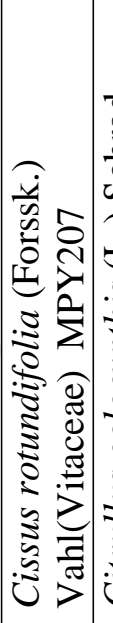 & 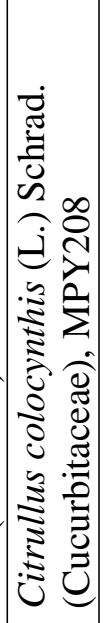 & 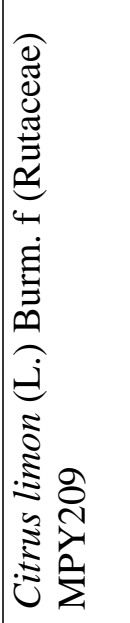 & 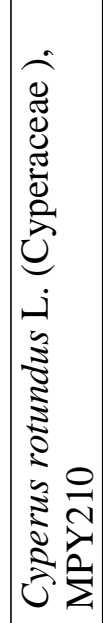 & 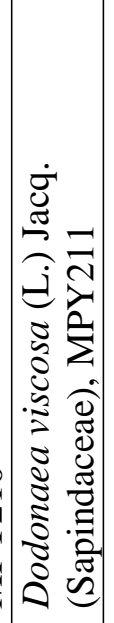 \\
\hline
\end{tabular}




\begin{tabular}{|c|c|c|c|c|c|c|c|}
\hline 요 & 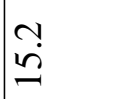 & $\stackrel{n}{\varrho}$ & $\begin{array}{l}\infty \\
\dot{N} \\
\text { in }\end{array}$ & $\stackrel{2}{2}$ & 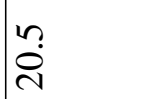 & 六 & $\underset{m}{\infty}$ \\
\hline$\stackrel{\varrho}{0}$ & $n$ & ฉ̆ & $\stackrel{\cong}{\cong}$ & 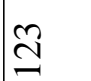 & $\overline{0}$ & $\ddot{\vartheta}$ & $\infty$ \\
\hline 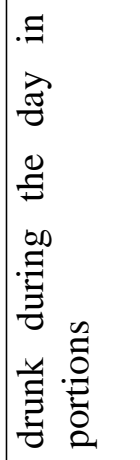 & 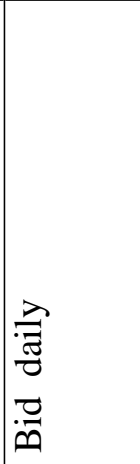 & 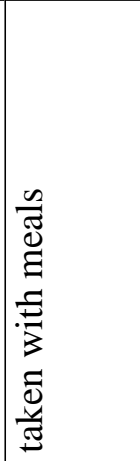 & 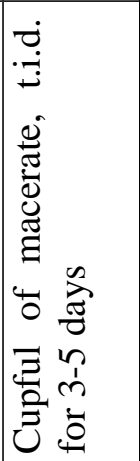 & 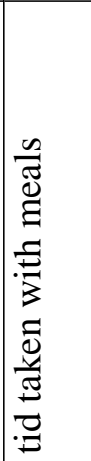 & 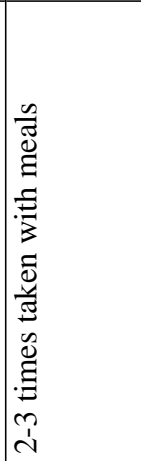 & 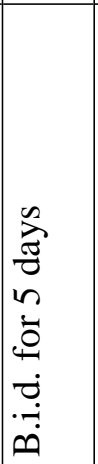 & 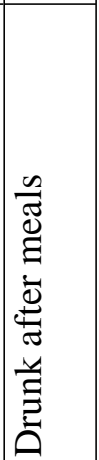 \\
\hline 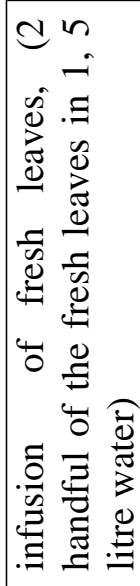 & 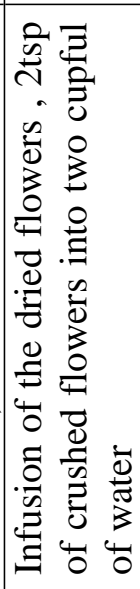 & 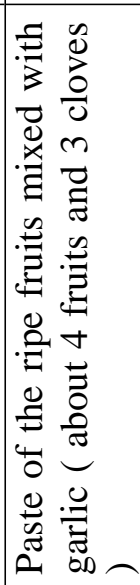 & 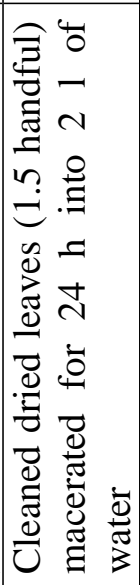 & 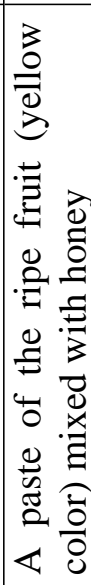 & 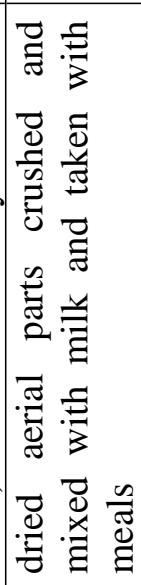 & 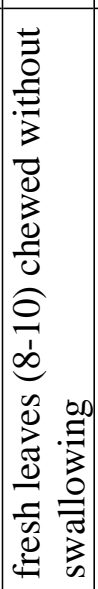 & 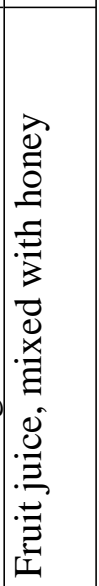 \\
\hline ـ & II & 点 & - & 空 & శิ & - & 它 \\
\hline 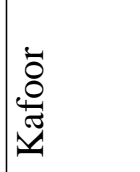 & 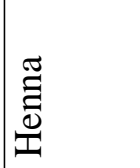 & 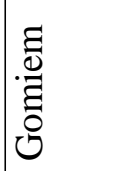 & 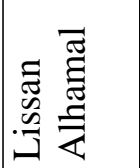 & 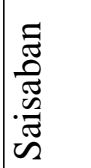 & $\mid \begin{array}{l}\frac{4}{\frac{d}{2}} \\
\frac{a}{2}\end{array}$ & 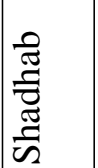 & 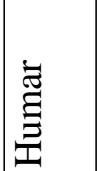 \\
\hline 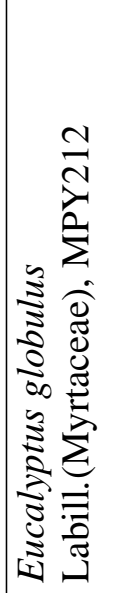 & 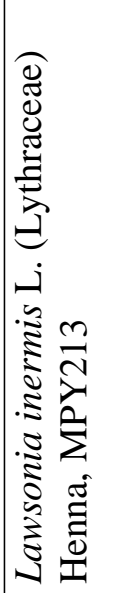 & 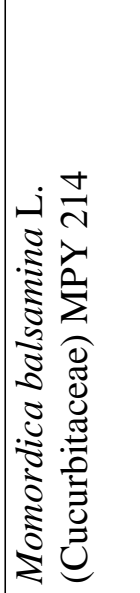 & 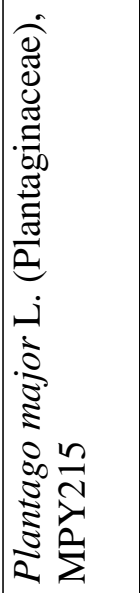 & 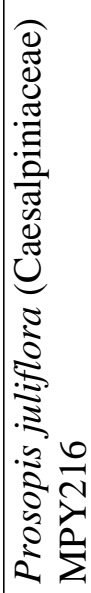 & 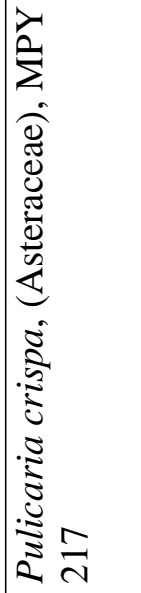 & 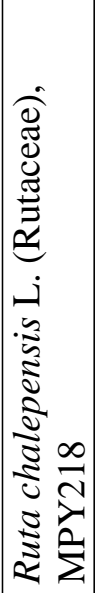 & 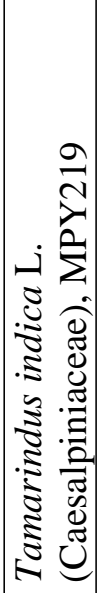 \\
\hline
\end{tabular}




\section{Afr. J. Trad. CAM (2004) 1: 72 - 76}

rotundifolia, Citrullus colocynthis, Anisotes trisulcus, and Tamarindus indica have not been reported so far. Therefore we recommend that screening of the above mentioned plants for antimalarial activity should be carried out on one hand in order to justify the local traditional uses and on the other hand to isolate and identify the active compounds, which may be regarded as future promising phytotherapeutics in the treatment of malaria.

\section{Acknowledgment}

The authors are grateful to WHO-office in Yemen for the kind support offered to this study.

\section{References}

Ali, Awadh A. N., Attif, O. A. and Mohammed, M. I. (1999). Herbal medicine in two Yemeni provinces -ethnobotanical study. Yemeni Medical J. 3:13-23

Fleurentin, J., Mazars, G. and Pelt, J.-M. (1983a) Additional information for a repertory of drugs and medicinal plants of Yemen. J. Ethnopharmacol. 8: 237-243.

Fleurentin, J. and Pelt, J.-M. (1983b). Additional information on the cultural background of drugs and medicinal plants of Yemen. J. Ethnopharmacol. 8: 335-344.

Fleurentin, J. and Pelt, J.-M., (1982). Repertory of drugs and medicinal plants of Yemen. J. Ethnopharmacol. 6: 85-108

MacKinnon, S., Durst, T.; Arnason, J. T., Angerhofer, C., Pezzuto, J., Sanchez-Vindas, P. E.; Poveda, L. J., Gbeassor, M. J. (1997) Antimalarial activity of tropical Meliaceae extracts and gedunin derivatives. J. Nat. Prod. 60: 336-341

Schoppen A. 1983. Traditionelle Heilmittel in Jemen. Franz Steiner Verlag GMBH.

Sittie, A. A., Lemmich, E., Olsen, C. E., Hviid, L., Kharazmi, A., Nkrumah, F. K. and Brogger Christensen, S. (1999). Structure -activity studies: in vitro antileishmanial and antimalarial activities of anthraquinone from Morinda lucida. Planta medica 65: $259-261$

Tan, R. X., Zheng, W.F. and Tang, H. Q. (1998). Biologically active substances from the genus Artemisia. Planta medica 64: 295-302

Thebtaranonth, C., Thebtaranonth, Y., Wanauppathamkul, S. and Yuthavong, Y. (1995). Antimalarial sesquiterpenes from tubers of Cyperus rotundus. Phytochemistry 40:125-128.

Wood, J. R. I. (1997). A handbook of the Yemen Flora, Whitstable Litho Printers Ltd, UK. World Health Organization,(1996). Malaria distribution. A weekly epidemiological record. 71 (3): $17-24$ 